\title{
Japan's Rejuvenation and the US-China Divide
}

The main focus of Japanese foreign affairs in Meiji, Taisho and even Showa eras concerned China ... but what was interesting is that the elite course for career advancement in the Ministry was not curiously, "China service" or looking after Japan's interest in China, and definitely not holding posts in Japanese Consulates in China. The sunniest road to success in the ministry had traditionally been assignments in capitals and large cities in Europe and the United States, such as London; Paris; Berlin; Washington D.C.

Prime Minister Yoshida Shigeru, 1961

If you consider the case of aggression carried out against Japan, will the UN protect us? Of course not. Japan cannot maintain peace and security for the nation all by itself, so we have signed the US-Japan Treaty ... I do not think the UN would form a UN force to protect Japan from invasion.

Prime Minister Junichiro Koizumi, 2004

It is necessary for the United States to take a fresh look at the relative value of Japan to the U.S. and the world, as well as what Japan has to offer to the U.S. and to the world ... Japan is not a dependent state, it's not a Puerto Rico to the U.S. and this is something both nations must recognize ... I think that the U.S. should be 
seriously questioning whether there is real value in defending Japan. The U.S. must be explicitly clear in its answer to this question. If the answer is no, then Japan will make up its own mind to defend itself, and our efforts to defend ourselves may lead to the nuclear armament that everyone is concerned about.

Tokyo Governor Ishihara Shintaro, 2012

\section{Japan's Asia Strategy and the US-China Challenge}

The onset of the Cold War and the subsequent implementation of the San Francisco system witnessed the birth of one of the most successful aboutturns in the bilateral relationship between the US and Japan. In a short span of six decades, it has moved from enmity to friendship. Over half a century, Japan steered clear of foreign military adventurism as it focused its efforts to grow its economy to become one of the largest in the world. Japan's relationship with China has taken on a very different trajectory. Like the US, the Chinese fought a bitter war with Japan. The conflict between China and Japan began about 44 years before the bombing of Pearl Harbor, in 1898, when the first Sino-Japanese war was fought. By the time the Japanese surrendered, China was deeply embroiled in a civil war between nationalist and communist forces. With the defeat of the nationalists, and the founding of the People's Republic, Japan's relations with China bifurcated into an official relationship with the nationalist Republic of China (at the behest of Washington) and an unofficial relationship with communist China that was constrained and low key. By 1972, with the realignment between the US and China, Japan followed suit and switched recognition between Beijing and Taipei. By the 1980s, relations between China and Japan reached new heights, last seen during the Tang dynasty. The end of the Cold War brought a diametrically opposite implication for Japan's relations with the US and its relations with China.

The US-Japan partnership was called into question in the early 1990s as the principal nemesis and the fundamental reason for the US-Japan alliance, the USSR, disintegrated. As Japan struggled to debate on the future of the alliance and the direction of its diplomacy, a parallel process was happening in China. Deng's reforms had taken off remarkably and in the 1990s, analysts from Washington to Singapore to Tokyo were debating the implications of the rapid rise of China economically and consequently politically and strategically. By the mid-1990s, differences between China and Japan began to surface. The rise of China has been particularly 
problematic over the last two decades for Japan. First, from Japan's vantage point, China is seen to be more aggressive as it grows its economy. Second, Sino-Japanese relations took a dip from the mid-1990s onwards over a range of issues: China's nuclear test, the Taiwan Straits Crisis, democratization issues in Hong Kong and Taiwan, confrontations over gas deposits in the East China Sea, and the issues over the Senkaku Islands. Domestically within Japan, generational change meant that the special place China held in the hearts of the wartime generation no longer was dominant in public narratives and worldviews. This shift in attitude was accompanied by a hardened nationalistic discourse. Mutual demonization in both China and Japan is now the norm, not the exception. The challenges are real, but their magnification by international and domestic media has created a real sense of urgency and crisis in Japan. This has generated a national consensus that the US-Japan alliance is to be reaffirmed to meet the challenges facing Japan, prompting a measured support to rally behind the neo-conservatives' agenda, even though it is against the grain of Japanese pacifist and democratic culture. Over the course of the next two decades, Japan's relations with China deteriorated drastically to the point that Beijing and Tokyo have become major strategic competitors in the truest sense of the world, locked in what analysts would term as the Thucydides' Trap, driven by insecurity, competing interests and a nationalistic struggle for honor.

Japan's relations with the US took on a very different trajectory. By the early 1990s, Washington and Tokyo came to a consensus that the alliance was needed to provide continued support to the peace and security that Asia has enjoyed since the end of the Vietnam War. First, international reactions to Japan's checkbook diplomacy in the aftermath of the Gulf War led to both shock and dismay within Japan. This prompted a rethinking and reorientation of Japanese diplomacy better to meet its international challenges, and also a deep hard introspective look at Japanese demands and needs from this bilateral relationship. Japan realizes that it cannot be as "disengaged" from the world as it was during the Cold War, and Japanese diplomacy has to match the aspirations of the new era. Second, Tokyo decided that the best strategy Japan could undertake was to engage or confront a rising China and a belligerent North Korea. China-Japan relations were for most part cordial from the 1970s till the mid-1990s, with the exception being the brief period that China came under sanctions for the Tiananmen Square incident. Until the late 1990s, China was never construed as a national security threat. By the mid-1990s, the "China threat" was discussed in moderate tones, but by the turn of the 
millennium, the hysteria over the North Korean missiles overflying Japan led to the framing of the rising China and a belligerent North Korea being discussed openly in Japan's security narratives. The US-Japan alliance was always portrayed by the US and its allies as the anchor of stability in the region (Armitage and Nye 2012).

The strategic threats and the election of Prime Minister Koizumi (April 2001-September 2006) provided the opportunity and basis for a conservative resurgence to emerge in Japan. Koizumi's priorities were never about China in the first place. His primary concerns were domestic and economic, and his political strategy relatively unorthodox. Until the September 11 attacks, he believed in adjusting Japan's foreign policy posture to ensure that Japan would continue fulfilling its international commitments. Koizumi's popularity was unprecedented largely because of two attributes. He had an excellent media team, which was very able in cultivating the tabloids as opposed to the traditional mainstream broadsheets, and generating public support independent of the traditional factional support system within the LDP. Thus, he was able to turn the tables on the powerful bureaucracy (such as the all-important Ministry of Finance and Ministry of Industry and Trade) and had the Kantei issue policies to the bureaucrats as opposed to being told what to do by the bureaucrats, as in the past. His popularity enabled him to challenge the traditional patronage system and pork-barrel politics and challenge powerful constituentsthe bureaucracy, big business and the LDP itself. His resolve to tackle the woefully inefficient postal savings system and to change the nature of politics led his era to be known as "The Koizumi Restoration" - an attempt to compare him to the Meiji elites (The Economist, September 14, 2006). The Economist also wistfully notes that he did not achieve the constitutional amendment, which is something he should have focused on, as was the disastrous China policy his successor inherited. Koizumi's popularity rested on the image that he projected to the electorate-his resistance to the LDP Party genros and their corrupt ways of doing things, and his preservation of traditional Japanese values and cultures, in particular his appreciation of all those who sacrificed themselves for their country. This is exemplified by his repeated annual visits to the Yasukuni Shrine, despite Chinese pressure. By the end of Koizumi's tenure in 2006, there was a popular joke between Chinese and Japanese analysts that the greatest achievement of Prime Minister Koizumi was that he had caused bilateral relations to deteriorate to the extent that they could not get any worseapart from outright declaration of war between China and Japan. 
The next several years (2006-2012) saw the rapid rise and descent of several prime ministers on a revolving door basis. Prime Minister Koizumi was succeeded by Prime Minister Abe (Sept. 2006-Sept. 2007), then Prime Minister Yasuo Fukuda (Sept. 2007-Sept. 2008) and then Prime Minister Taro Aso (Sept. 2008-Sept. 2009) and finally, before the LDP was defeated at the polls, by Yukio Hatoyama (Sept. 2009-June 2010) of the DPJ. The DPJ's tenure did not last very long as Hatoyama was successively replaced by Naoto Kan (June 2010-Sept. 2011) and Yoshihiko Noda (Sept. 2011-Dec. 2012). Prime Minister Abe won the second election and became the second longest-serving prime minister in postwar Japan.

There are two reasons why Sino-Japanese relations deteriorated during Koizumi's era. The first concerned the latitude that the prime minister had in foreign affairs, particular in his dealings with China. Distracted by the Wars on Terror, the Bush administration neither had the time, expertise nor attention to keep track of what was going on between China and Japan. Both were important allies in the War on Terror, and US foreign policy played a relatively neutral role in their contestation over interpretations of history and other issues. Despite this, the US emerged out of this period as the clear winner in its Asian strategy, simply because Japan had embraced the US-Japan alliance tighter as Sino-Japanese relations spiraled downwards, and the Chinese in turn felt helpless over the maverick politicians in Tokyo they had little sway over. Many in Beijing felt that only the US could reason with the Japanese, and if the US-Japan alliance was tightened, then this might be a good thing as Beijing could rely on the US to sway or tame Tokyo. Consequently, by the time Koizumi's era ended, both Tokyo and Beijing were reaching out to the US as a mediator of sorts to calm issues between them. The Bush administration's hands-off policy had paid off surreptitiously.

Prime Minister Koizumi's immediate successor was his chief cabinet secretary Shinzo Abe. In his first term as prime minister, Abe started by making constitutional amendment a priority, but this did not go down well with the electorate, as many of the Japanese voters had voted LDP because of their desire for economic growth and stability. Prime Minister Yasuo Fukuda largely helped heal Sino-Japanese relations by signaling Japan's desire to work with China and signed the fourth political instrument that contemporary Sino-Japanese relations is predicated upon, with both China and Japan agreeing to premise their relations upon "mutually beneficial strategic interests." 
This period of brief respite did not last very long, as by 2010 the Chinese and Japanese were at loggerheads over the detention of a Chinese boat crew that had been fishing off the vicinity of the Senkaku Islands. It involved a high-speed chase in which the boat crew is alleged to have rammed one of the Japanese Coast Guard ships. Japan released the video of the chase and the incident inflamed nationalistic sentiments on both sides. The episode only ended when the Chinese arrested four Japanese nationals for espionage (with the prospects of a capital sentence) and only then did Japan release the Chinese nationals.

To date, most of the efforts in "normalizing" Japan focused on chipping away at the constraints imposed by Japan's constitution so that the US-Japan alliance could function more effectively (Martin 2016). Hence from the mid-1990s onwards, Japan has instituted frequent bilateral meetings with the US to work out measures to tighten the alliance through more frequent working consultations, passing primary and secondary legislation to facilitate the alliance. This started in earnest after the Japan-US Joint Declaration on Security Alliance for the twenty-first century (The Clinton-Hashimoto agreement) in 1996, and has continued largely unabated to this day. This primary and secondary legislation, as well as discussions and dialogs, allowed for JSDF operations to be harmonized with the missions of the US missions, and legitimized the deployments of JSDF units beyond traditional geographical and functional constraints.

From Japan's point of view, these series of steps to "normalize" Japan would not only enhance the operational capability of the US-Japan alliance, but more effectively politically legitimize and legalize the role of Japan in regional and international security. This development also restored a certain "balance" to Japan's foreign policy as it removed one of the main criticisms levied at Japan as a "free-rider" in the alliance, enabling Japan to mature into a more "responsible" partner in terms of burden and risk sharing.

With the re-election of Prime Minister Abe in 2012, there was no question that the neo-conservative element's agenda of bringing incremental reforms to Japan's political institutions took on an added momentum (Soeya 2012; Martin 2016; McCormack 2016). Prime Minister Abe enacted a "proactive pacifism" doctrine, promising to transform Japan's security policy and enable Japan to exercise the right of "collective selfdefense," which was actually unconstitutional until the prime minister changed its interpretation (Akimoto 2018). Even though this was somewhat controversial, it must be remembered that it was Prime Minister Yoshida (and subsequently all other prime ministers) who had used a very 
conservative interpretation of Article 9 to fend off US pressure to rearm. Prime Minister Abe went against the grain and did the exact opposite of his Cold War predecessors: He remilitarized and increased Japan's global engagement (Kingston 2016).

One of the most important documents is the 1979 Guidelines for US-Japan Defense Cooperation, which was revised in 1997 and 2013. Under the new guidelines, the US and Japan recognized and planned for a greater and more flexible response to the possible threats surrounding Japan. On October 8, 2014, Japan and the US announced the publication of an interim review report on the six-decade US-Japan alliance. ${ }^{1}$ This review effectively removed the geographical constraints on the US-Japan alliance that previously limited it to the "situations in areas surrounding Japan" established by a similar review in $1997 .^{2}$ This report also complements Japan's decision to change its interpretation of its constitution and lift the ban on collective self-defense in July 2014 that effectively allowed Japan to use military force to assist its principal ally, the US, should it come under attack. The October report further indicated that the US-Japan alliance would remain a cornerstone of US policy in Asia's and Japan's foreign policy for the next quarter of the century, cementing the cooperation between the US in marine safety, intelligence gathering and missile defense, from "peacetime to contingencies." This development not only broke from Japan's pacifist tradition, but enabled Japan basically to intervene in an operation, should the US go to war in the name of self-defense, or enter a conflict that extended well beyond its backyard. This of course has raised concerns, not only from China but also from other US allies such as South Korea. ${ }^{3}$ Many Japanese mistakenly believe that the Chinese or Korean governments are not convinced that they have been rehabilitated-this is not strictly true. Most Chinese and Koreans think the world of Japanese people and culture-it's the Japanese politicians that they have trouble trusting.

Prime Minister Abe also lifted the ban on weapons exports in the same year in the same creative manner that Japan had used when defending the Senkaku Islands. Tokyo had skirted the constitutional constraints on

\footnotetext{
${ }^{1}$ See media release by the US Department of State, October 8, 2014, http://www.state. $\mathrm{gov} / \mathrm{r} / \mathrm{pa} / \mathrm{prs} / \mathrm{ps} / 2014 / 10 / 232694 . \mathrm{htm}$

${ }^{2}$ See The Guidelines for Japan-US Defense Co-operation, http://www.mofa.go.jp/ region/n-america/us/security/guideline 2 .html

3 "U.S. official reassures South Korea over revision of defense guidelines with Japan," Kyodo News Agency, http://www.japantimes.co.jp/news/2014/10/06/national/politicsdiplomacy/u-s-official-reassures-south-korea-over-revision-of-defense-guidelines-withjapan/\#.VDwgxL5UhT8
} 
increasing the armament of the maritime self-defense forces by transferring Japan's bigger warships to the Coast Guard. Deployments against Chinese vessels in the territorial waters around Senkaku actually constitute police enforcement action. In lifting this weapons ban, the prime minister has mandated that the weapons exports and transfers are made under the "overseas development assistance" packages. This allows for direct military ties to Southeast and South Asian countries, as the ODA rules allow for capacity and infrastructure building. The same weapons ban lift also applies to military technology transfer between allies (Jain 2017). Currently, Japan has only been successful in selling arms to three countries of significance to the South China Sea-the Philippines, Vietnam and India (Pejsova and Stanley-Lockman 2016). The Philippines (2013) and Vietnam received "donations" or "loans"- these are the two countries with the most antagonistic relations with China. The Philippines Coast Guard (PCG) received five patrol aircrafts as part of the bilateral Maritime Safety Capability Improvement Project, and a ten vessel donation in 2016, while the Vietnamese received in 2014, six secondhand vessels and also P-3C antisubmarine aircrafts. Japan is also in talks to sell 12 amphibious U2 Aircraft to India to allow it to beef up its maritime patrols in the Indian Ocean (Pejsova and Stanley-Lockman 2016). Japan has also tried its very best to rope India into the US-Japan alliance, but the effectiveness of India as an alliance partner remains to be seen.

Hideaki Watanabe, head of Japan's Defense Agency's Acquisition, Technology and Logistics Agency said that Japan's attempt to share weapons technology with ASEAN states is in direct response to "aggressive" attempts to change the status quo by some nations (Straits Times, June 12, 2017). Even though Prime Minister Abe is linking ODA with defense capability development and has built up the defense capacity of these states, there are limitations. First, much depends on the personal politics of the leaders. Then, the Philippines President Benigno Aquino III was staunchly pro-US and hence very anti-China, but his successor, President Rodrigo Duterte is pro-China. The latter, however, maintains good relations with both President Xi and Prime Minister Abe, accepting loans and aid from both sides. Thus, the attempt to rally Southeast Asian states against China is an on-going tussle, with no clear winners because ASEAN states usually remain neutral. On top of this, weapons donations alone are hardly adequate. Even if their capabilities are beefed up, these countries are still no match for China's military, nor have they been able to stop China from reclaiming and building artificial reefs in the region. 


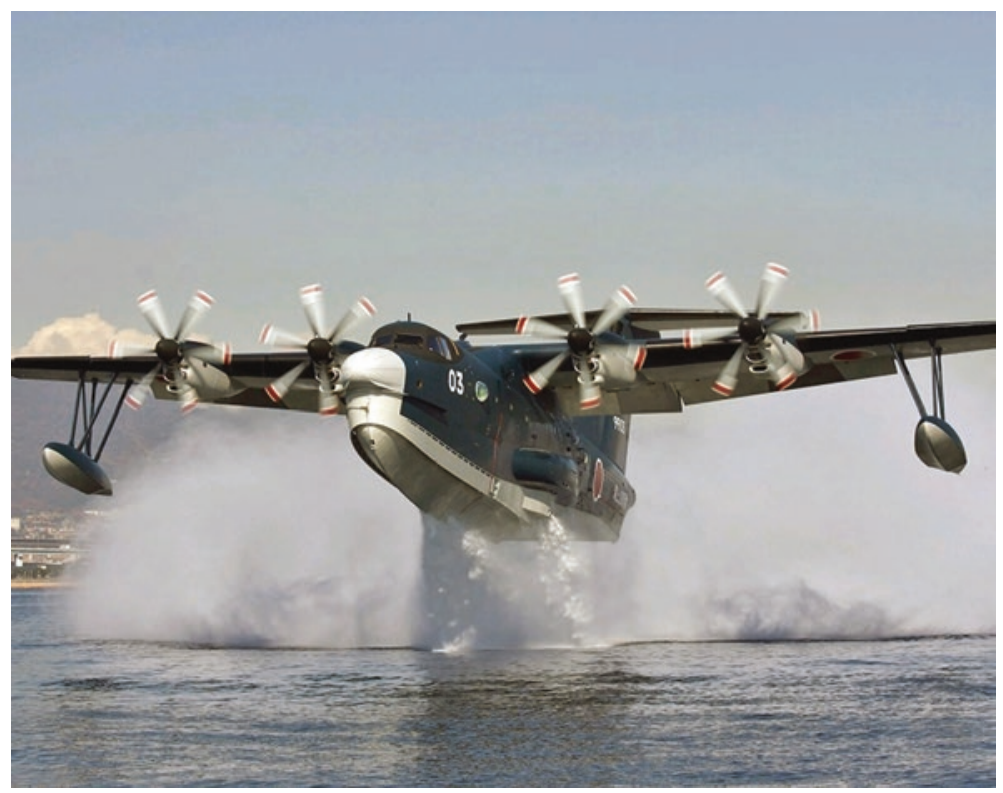

Photo: Japan lifted the ban on military exports and hardware in 2014. Japan is now exporting aircraft and vessels to countries such as the Philippines and Vietnam as a feature of its ODA, to "strengthen capacity." Japan is also negotiating with India about selling military aircraft. (Photo of a JSDF amphibious aircraft. The work is licensed under the Government of Japan Standard Terms of Use (Ver.2.0). The Terms of Use are compatible with the Creative Common Attribution License 4.0 International; image available: https://commons.wikimedia.org/wiki/ File:Japan_Maritime_Self-Defense_Force_butai01_-_01.jpg)

\section{Cautioning America's Unilateralism}

There are of course politicians and segments of Japanese society who have imperatives to seek some sort of rebalance in Japan's relationship with the US, particularly with the election of Donald Trump. There are two reasons. The first of course has to do with Japan's indigenous development. The Cold War is over and Japan is no longer the weak, defeated nation it was after the Pacific War. The US-Japan alliance was conceived for a very different purpose and under very different circumstances. There is a recognition that even though the Yoshida Doctrine has served Japan well, it was also a shrewd neo-realist realpolitik maneuver on the part of Japan to make 
the best use of its circumstances at that time. The Yoshida Doctrine provided a shield used by successive Japanese prime ministers to resist US pressure for Japan to rearm or commit politically and militarily to fight the Cold War. Even though pacifism and the Yoshida Doctrine is being sold as a liability of the past and a legacy of the San Francisco system, the truth is that it was a question of judgment and interpretation of the Kantei (prime minister's office) as to which strategic direction to lean toward. Over the past two decades, the neo-conservatives have successfully managed to direct the political and strategic narratives to cast China as the dominant threat, and the US as the dominant savior and friend that can help Japan enhance its own security and protect its freedom. At another level, it might be even possible that the Japanese elites believe that only through the tightening of its embrace of the US, would it be bestowed with the trust and the latitude to rejuvenate as a global power. This is not something new.

Back in the 1970s, it was abundantly clear that Japan then was already keen to use its new-found economic strength in order to increase its power and leverage over the countries it provided assistance to. By the late 1980s, Japan was no longer the "weak" war-torn nation in the aftermath of the Second World War. ${ }^{4}$ In military terms, Japan possesses the most formidable hardware in the whole of East Asia. It is only natural that Japan would seek to achieve political status commensurate with its level of economic development. However, by the 1980s, there were increased strains in the US-Japan relations, as politicians and scholars in the US debate the strength of their ally. The incessant Japanese purchase of prime real estate in Manhattan and Los Angeles, the rise of Japan's technological and manufacturing prowess and the dominance of the Japanese yen all but suggest that, in its economic ascent, Japan would threaten to overshadow the US. Japan's rise during the 1980s foreshadowed a similar path that China would take about three decades later. Yet, by the 1990s, Japan's rise was stymied by a variety of political and economic factors, but many Japanese commentators privately groused that US containment was at least part of the reason for Japan's failed rejuvenation.

\footnotetext{
${ }^{4}$ By almost all measures, Japan is an extremely wealthy and powerful nation. Until 2010 , Japan was the world's second largest economy. World Bank data showed that in 2017, Japan's GDP was USD 4872 trillion, and on a per capita basis, USD 38,428. Even though China's economy overtook Japan's as the second largest economy in the last quarter of 2010 (China GDP for 2013 was USD 9.24 trillion), Japan's GDP per capita basis is still over six times that of China's (USD 6807). Therefore, at the height of its supposed stagnation, the average Japanese person was not feeling the effects of the so-called "depression."
} 
However, this did not quell Japan's ambition to normalize or its desire for rejuvenation as a global power. The end of the Gulf War and the rise of China provided further impetuses. The lessons learned during the 1980s have not been forgotten, even though they are not articulated too loudly in Japan today lest it prematurely depletes one's political capital. With the new generation coming to the fore, and the dominance of the media in framing the nation's challenges, the concerns of pacifism have been completely overwhelmed by the seemingly difficult political and strategic circumstances Japan faces externally. For that reason, traditional concerns with the US are articulated in private discourse, not public narratives. Any politician who dared to question the role of the US or question the sacrosanctity of the US-Japan alliance would have his political career end prematurely. One need not look far. Prime Minister Hatoyama came to power promising he would seek to restore a balance in Japan's relations with the US and seek better relations with its Asian neighbors-he only lasted nine months. There were widespread criticisms against the DPJ-both domestically and internationally.

Hatoyama's successors, Prime Minister Naoto Kan and Prime Minister Yoshihiko Noda, did not fare better from the challenges posed by great power contestations. Prime Minister Kan first faced his challenge in the form of the trawler boat collision incident near the Senkaku Islands in 2010 , as mentioned earlier. The simmering tensions from this incident did not subside, and by 2012 an even bigger incident occurred.

The DPJ faced its most severe crisis yet in 2012. Ishihara Shintaro and Hashimoto Toru, who were then planning to set up an independent party in Tokyo and Osaka respectively, hatched a plan for the Tokyo metropolitan area to "purchase" the Senkaku Islands. On April 16, 2012, the Tokyo governor announced that the Tokyo municipality government would purchase the islands from their private owners (Straits Times, April 16, 2012). This immediately provoked reactions from the people and governments of China and Taiwan. During the summer of 2012, Hong Kong activists and Japanese activists both visited the islands to plant their respective flags to claim sovereignty. In September 2012, widespread protests broke out in approximately 125 cities across China, with widespread damage caused to Japanese businesses and interests that belonged not just to the Japanese but also to the Chinese.

This crisis provided Shinzo Abe with an opportunity to actively bring forth a series of measures (as discussed in Chap. 2) to effect changes across the three central pillars of Japan's rejuvenation at policy administration, 
legislative and political level (Ichiyo 2016; Tawara 2017). It is not known to what extent Ishihara and Abe acted in concert but again, as discussed previously, even though nationalists and neo-conservatives are technically very different, there is consensus when it comes to the harkening of traditional culture and values as mobilizing vehicles for their platforms. By the end of the crisis, Ishihara had launched his new party with Hashimoto Toru, which devastated DPJ's foreign policy platform, helped Shinzo Abe win the elections and drove all factions and political parties further rightwards with regards to China. This heightened and in the process reignited and mobilized both Japanese and Chinese nationalism. This episode effectively finished the DPJ politically. Even Beijing preferred the incoming LDP to the DPJ, simply because they could at least find the person who was in charge of Japan to talk to (even if he was a neo-conservative).

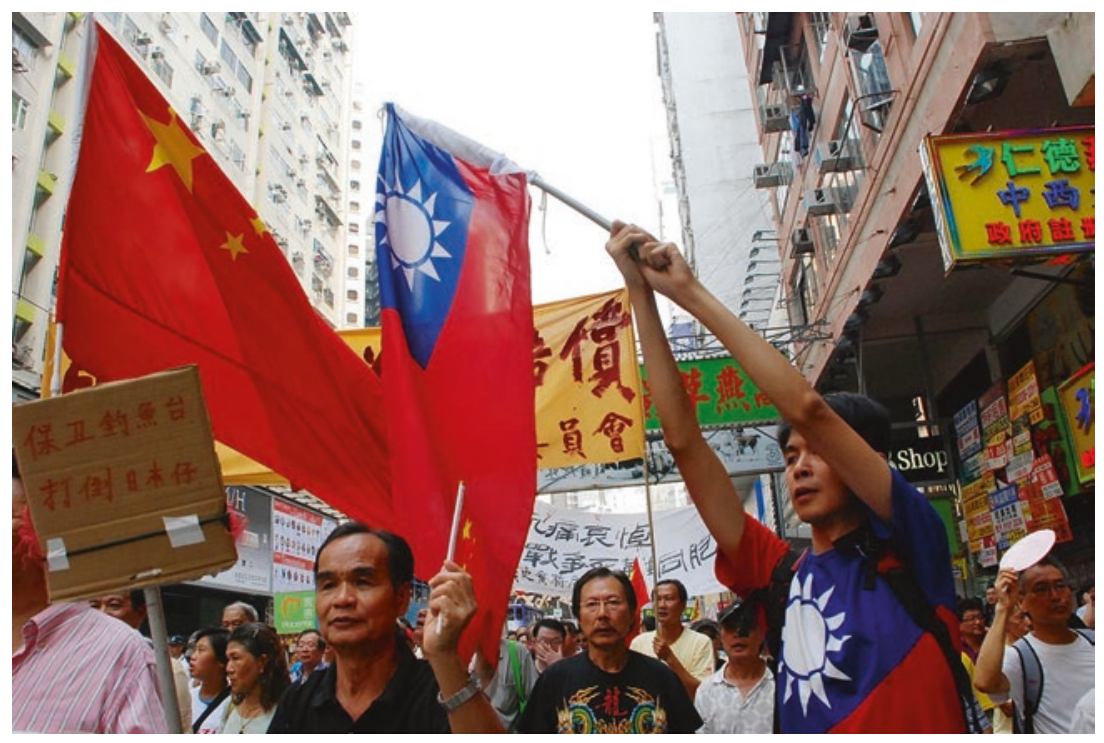

Photo: Protestors in Hong Kong on September 12, 2012, brandishing a Taiwanese flag and a Hong Kong flag. (Public domain photo, Photo source: https://www.voacantonese.com/a/hk-activists-to-hold-march-on-defendingdiaoyu-islands-live-qa/1508949.html)

The handling of the nationalization of the Senkaku Islands was regarded as rightful in some quarters in Japan, while there were contrarian views 
that Japan was risking war to save the US-Japan alliance, as most constituents in Japan's political entity did not expect this kind of response from China - even though the country's ambassador to China, Uichiro Niwa, had warned in June 2011, after communications with the Chinese, that a move to "nationalize" the islands would trigger an "extremely grave crisis" and "decades of past efforts would be brought to nothing" (Financial Times, June 6, 2012; Straits Times, January 28, 2018). There is a view that Japan's almost "reckless" behavior in attempting to "purchase" the islands was not an administrative blunder caused by the DPJ's inexperience in foreign policy in general or with China in particular, but rather an all-out attempt by conservative elements within Japan to forestall the realization of a greater threat-that the US and China might have been moving toward a new East Asian shared paradigm by which they would adopt a shared security architecture (Harner 2012; White 2013). This is the classic "abandonment" dilemma of alliance theory.

Shinzo Abe's victory came on the heels of the US "pivot" to Asia after Secretary Clinton announced President Obama's new initiative to focus on Asia. While Japan was contesting China in the East China Sea, the Philippines and Vietnam confronted China in the South China Sea. The US pivot rested nicely on these fulcrum points. What was happening in the East China Sea must be contextualized against a larger hegemonic struggle that was going on in the South China Sea. This happy coincidence of the rise of the Abe 2.0 administration, coupled with the refocusing of US policy, meant that the alliance became even more important in taking down China, by now widely perceived as an irredentist systemic challenger.

The argument against overreliance on the US-Japan security alliance is well rehearsed and often heard: is it too much for Japan to trust the US to go to war for them against China in order to defend Japanese interests? Apart from its military strength, today's China is stronger in almost every way than the USSR was. China believes that time is on its side; if anything, the aggressive diplomatic maneuvers on the part of the US in response to China's emerging Ocean strategy is a reaffirmation of this view. As the quote from former Tokyo Governor Ishihara shows, a real but unspoken thought in Japanese minds is how far would the US go to defend Japanese interests against China. Despite the promises of senior US officials and successive presidents, Japanese officials wonder privately if Washington's actions would match up to its rhetoric, especially if the conflict was over something that Washington considered non-essential. Beyond that, being 
chain-ganged into a conflict with China is something that Tokyo should not take lightly, given the Trump presidency. The treaty binds Japan to US military action that is decided primarily in Washington D.C. Not all issues that crop up in a US-China confrontation would necessarily involve Japan, and even if they did, Japanese domestic circumstances or national consensus might not allow Tokyo to intervene. In order to enhance the military aspects of Japan's normalization, the Japanese government has over the course of the last 15 years striven to beef up its military strength, even though it is confined by the US-Japan alliance. Regardless of what the official position is, from a theoretical perspective, tightening the alliance under the guise of "normalization," even though convenient, is likely to make Japan more dependent rather than less.

It is this overt dependency that should be reconsidered. The inhibiting constraints of the US-Japan security alliance is well known and well understood by most Japanese commentators and US officials. One need not look far-the literature on technological cooperation between the US and Japan in the field of high-tech defense, such as in space cooperation or the Joint Strike fighter, is replete with these references. Officially, the treaty puts the US and Japan on equal footing as allies. Unofficially, even though the treaty has appeared from different angles to treat the US and Japan on unfair terms, what is surprising is how officials in both countries have consistently managed and interpreted the alliance to their advantage, and persuaded domestic audiences and third parties of its worth.

From the Japanese perspective, there are three important reasons for doing so. First, Japanese officials are of the view that this partnership, despite its imperfections and issues, provides Japan with the easiest, best and cheapest security insurance for them to hedge militarily against China. This is a neighborhood security concern, and backyard fires triumph security concerns elsewhere. The second reason is tactical. Given Japan's penchant for a political low profile and relative inexperience in global affairs, partnering with the US might offer them relatively low barriers of entry into the affairs of regions afar. With decades of experience under their belt, riding alongside the superpower through the alliance is a great way to sell the alliance both at home and reassure Japanese neighbors abroad. Third, it socializes China to the fact that Japan can and will act in concert with the US to defend itself, and that China has little or no chance of prying this alliance apart. Most importantly, the tightening of embrace prevents China from usurping Japan's role in the alliance. This fear of abandon- 
ment is as real as the fear of entrapment into a war caused by excessive American adventurism.

From a distant viewpoint, Tokyo has largely ignored the constraints imposed upon Japan by the US. As long as Japan is unable to fully speak for its own defense requirements, conceptualize its own strategic ambitions or stipulate its national interests abroad, Japan will always be a "subnormal" country. Thus, one of the most important but unspoken subtexts of normalization that needs to be considered is its relationship with the US, not just China. Even though the US-Japan alliance appears more robust than in any previous period, there is always an element of tension between Tokyo and Washington to define and redefine the terms of their relationship. ${ }^{5}$

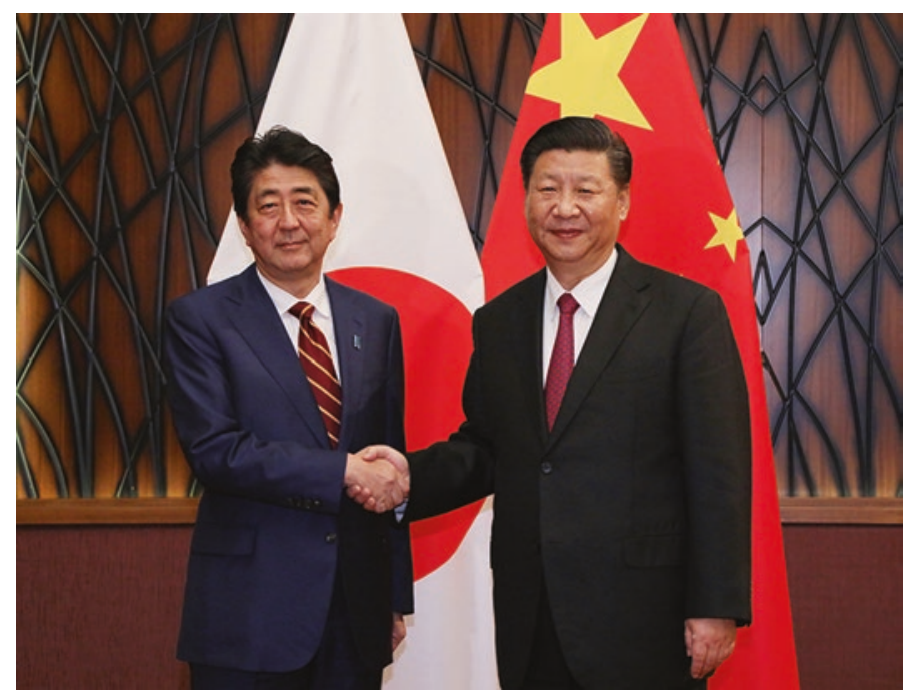

Photo: Prime Minister Shinzo Abe and Chinese Xi Jinping at an APEC Meeting in November 2017. (This work is licensed under the Government of Japan Standard Terms of Use (Ver.2.0). The Terms of Use are compatible with the Creative Commons Attribution License 4.0 International; image available: http:/ / www.kantei.go.jp/jp/98_abe/actions/20171l/1lapec.html)

${ }^{5}$ There has always been a contestation between the US and Japan in terms of research and development, particularly in high-tech industries such as the aerospace sector and defense industries (Green 1995; Samuels, 1994, 2007). 


\section{Is the “Anti-China” Position Necessarily Conducive TO JAPANESE INTERESTS?}

A prominent retired foreign ministry official and former ambassador, Ukeru Magosaki, has argued that the primary goal of US policy has always been to advance US interests, not Japan's interests (mainly). Therefore, US policy determined the kind of sacrifices that Japan needed to make that were not in Japan's interests. As the former ambassador to Iran, Magosaki frequently cited the example of the development of an oil field in Iran where the concession had already been won by Japan but which it was forced to give up to China instead. A Japanese diplomat told the author that Ambassador Magosaki's thinking is an exception and "un-Japanese"a code for not following the direction of the majority. This is interesting because it speaks to the extent to which most of the diplomatic corps, bureaucrats and scholars in Japan are willing to explain away the problematic aspects of US-Japan cooperation unconditionally. Another example of an important sacrifice is the issue of Okinawa. After almost three decades of post-Cold War years, Japan (in particular Okinawa) continues to host over 35,000 troops, and 5000 military related personnel in bases across Japan, even though Tokyo builds on its indigenous capability. In short, the democratic rights of those who oppose these bases have been ignored and violated (McCormack 2010; Araki 2012). Again, scholars outside Japan who articulate these views are not given the attention and time they deserve.

Magosaki argues that this is problematic as from the long term perspective the US has changed its policy at different junctures, and demanded that Tokyo should adhere to these policies even when it violated its constitution or ran contrary to its interests. Recent history is replete with these examples: asking Japan to rearm almost immediately after imposing the constitution on it as the Cold War set in; keeping nuclear weapons on its naval vessels, despite Japan's Three Non-Nuclear Principles; curbing the rise of Japan in the 1980s (e.g. preventing Japan from acquiring indigenous capability in many sensitive high-tech fields); reversing its policy on China (1972) and North Korea (2018) and not notifying Japan.

The China factor has therefore always loomed large. For the initial part of the Cold War, Sino-US relations were under strain, and therefore the US always blocked the prospects of Sino-Japanese reconciliation and bridge building between the Japanese and Chinese people. Like Hugh White, Magosaki suggests that Japan should not be too comfortable with 
the US approach with China as there is a tendency on the part of the US to negotiate with China to find a modus vivendi and sacrifice Japan's interests. In other words, Japan would be like a "pawn" or a "rook" in a chess game.

The question facing Japanese elites is therefore this: By treating the Chinese as a military threat, will this vision change into a reality? Yet for China to cause disruption to its neighbors or pose a threat, China need not use force. In the past, Chinese leaders have always maintained that all they had to do was to let their border guards go on leave and Southeast Asia would be flooded with Chinese migrants. Humanitarian concerns such as infectious diseases, poisonous food stuff, and fake goods such as medicines and other consumables would continue to flow from China. These are probably the real dangers to China's neighbors as opposed to a military invasion. Even though the various island disputes in the East and South China Seas have existed since the 1970s, they have never had the kind of contestation and contention we have seen in the last decade. The entry of the US and Japan into the South China Sea dispute had internationalized and politicized what was essentially a bilateral dispute into a multilateral one. During the 1990s, there was hardly any mention of the Spratly dispute, even though all the claimants had dug into the same position as they had today.

Also, beyond the Asia-Pacific, there are regions that have been more amicable to a Chinese presence than they have been to the US, simply because of historical dynamics. Today, most Arab countries prefer strong political relations with China (regardless of their relationships with the US), simply because they all believe China to be capable of being a counterweight to the US. China also has had a long experience with the developing world, given its status and role in countries that many G7 shunned, such as Sudan, Angola and others in Africa. The US and the rest of the G7 might have limited ability to engage in these areas, whereas Beijing might have better luck. If China and Japan are able to have a sustained and more in-depth dialog on the possibilities of joint engagement with these countries to improve their conditions, then Japan might increase its political role in these areas much quicker. This would also certainly help improve confidence in their bilateral relations. ${ }^{6}$

\footnotetext{
${ }^{6}$ There is a sign that this is already happening as China and Japan already reached an agreement to consider joint building of infrastructure in third countries during Prime Minister
} 
Furthermore, a tight embrace of the US will prevent the US from leaving the alliance, and this is not something that China will oppose fundamentally. However, the rhetoric cannot be sharply anti-China, simply because public opinion would drive the Chinese to take a harder stance. In short, reducing the anti-China hysteria would improve relations with China and increase security, not reduce it. Maintaining a hardline posture would only invite escalation. Many Japanese analysts have cited privately that Beijing "understands" the nature of competitive electoral politics, but they underestimate the emotive and nationalistic response it might build in China. The lack of high level contact between China and Japan between 2011 and 2018 is certainly a case in point.

\section{The Contestation in Southeast Asia: Winning Hearts AND Minds}

Southeast Asia has always been a traditional backyard for both China and Japan. Since the 1990s, Sino-Southeast Asia has been relatively warm. China sought to calm the Southeast nation fears in the mid-1990s when it displayed willingness to abide by a code of conduct for the South China Sea (Catley and Keliat 1997; Lo 2007), and subscribed to ASEAN's preference for multilateral as opposed to bilateral negotiations with regards to the South China Sea disputes (Chin 2003). For the last two decades, China has provided much of the momentum for the economic development of the region, averaging $9-12 \%$ of growth each year. Overall trade with ASEAN has increased. In 1997, with the onset of the Asian financial crisis, China's role left an indelible impression upon the Southeast Asian countries, and most if not all were to an extent grateful to China for its steadfast position in not devaluing the $\mathrm{RMB}$ and driving the region into another round of speculative devaluation (Gurtner 1999). This is accentuated by the fact that the US, the principal power in Asia, suffered a relative (if somewhat temporary) decline in its stature when viewed from the eyes of its allies and enemies alike.

With the onset of the War of Terrorism, the US myopic focus on terrorism meant that it was slow to react to the series of issues affecting East

Shinzo Abe's visit to China in October 2018 to celebrate the fortieth anniversary of the Treaty of Peace and Friendship between China and Japan. 
and Southeast Asia. From the Sino-Japanese spat that escalated during Prime Minister Koizumi's reign (2000-2005) to the outbreak of the SARS (2003) and bird flu (2005) epidemics, to the Korean nuclear crisis and the dispute over the Spratly Islands, Southeast Asians came to realize two things. First, the power of the US as the global and region hegemon is limited when it comes to these issues and second, that the role China plays in these events (and subsequent repeats of these events) is critical and can have a decisive outcome on the region. It is therefore in the region's interest to encourage and socialize China into playing a constructive if not leading role in these events. Rightly or wrongly, China's role in the events conveys the impression that China's ascendance is inevitable, and its Asian neighbors had better jump on the bandwagon to welcome its rise. Even Vietnam and the Philippines were looking to further their relations with China.

Yet, by the mid-2000s, as China's economy grew from strength to strength, Southeast Asians watched anxiously the direct tensions of the bilateral Sino-Japanese issues on one hand, and increased China-Japan spillover competition in Southeast Asia on the other. Beyond trying to outdo each other in development projects, technology transfer or expanding their influence and market share, Tokyo and Beijing lobbied for influence among the ASEAN countries. As a group, the ASEAN region was blessed as both China and Japan slugged it out to pour money into the regional economies as investment for influence. Even though the countries accepted assistance and money from both, some members of ASEAN were effectively lobbying the US to try and play a mediating role between the two. ASEAN members too held a consensus that the region should try and limit great power competition to prevent another "Vietnam" from happening.

The Spratly Islands dispute has been dormant for the most part of its existence. There are six claimants in the dispute, each claiming in part or whole the sovereignty of the islands concerned: China, Malaysia, the Philippines, Taiwan and Vietnam, with Brunei laying claims to the waterways but not the islands. Each of the claimants (Brunei excepted) has militarily occupied some of the islands and reefs concerned. 


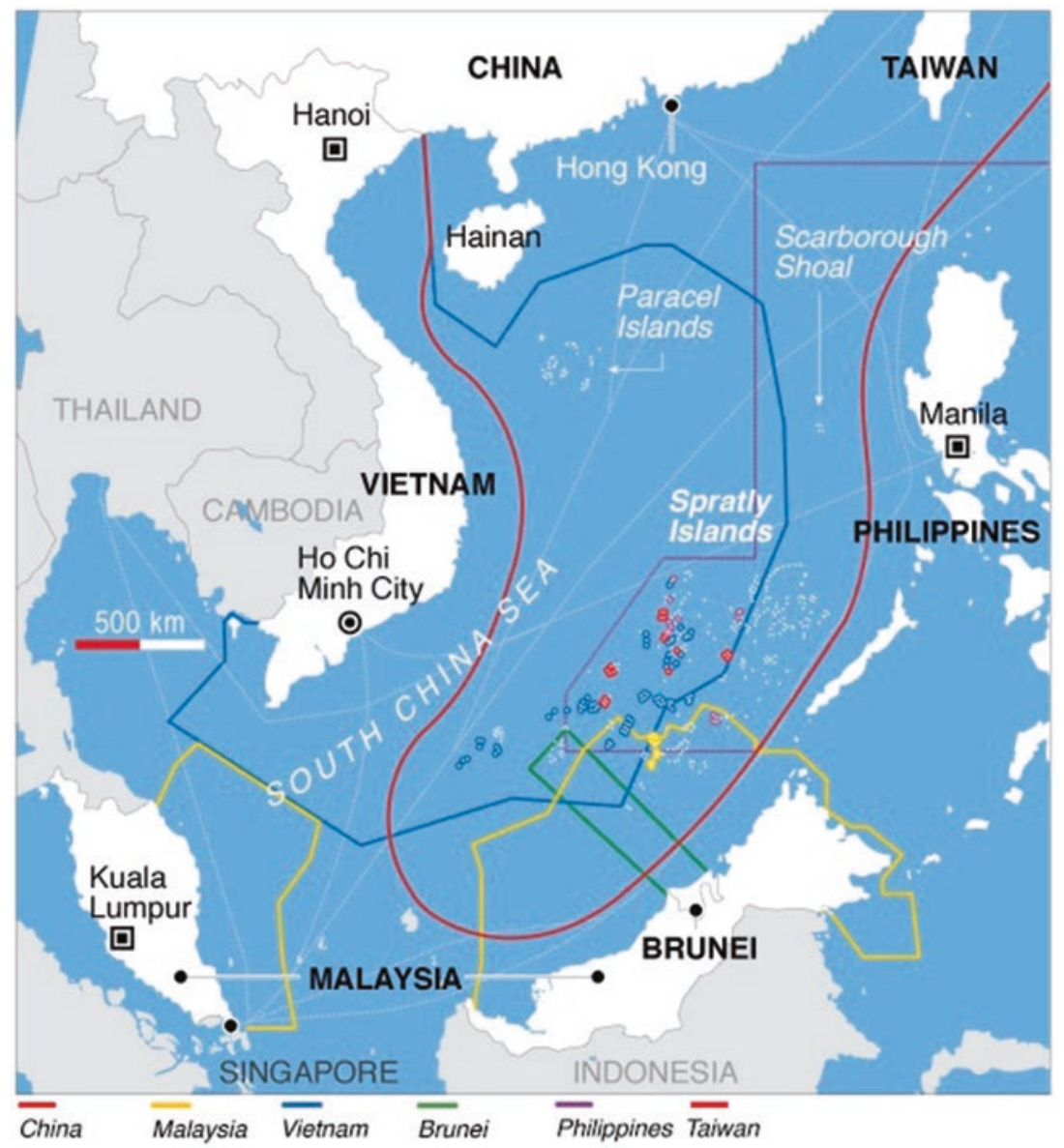

Plate: Territorial claims in the South China Sea (US State Department Picture 2012. Public Domain Picture by Voice of America, US Department of State, https://en.wikipedia.org/wiki/Territorial_disputes_in_the_South_China_Sea\#/ media/File:South_China_Sea_claims_map.jpg)

In the meantime, China fought naval skirmishes with the Vietnamese in 1984 and 1988 over the Paracel Islands, but like the Spratly Islands, the Paracel dispute was largely dormant until the turn of the century. Since the mid-2000s, the claimants have been filing reports over the presence of 
Chinese (or other claimants') fishing and naval vessels in their territorial waters.

There are three issues that offend the Southeast Asian states. First, the 1947 9-dash line drawn up by the Chinese government laid claim to almost all of the South China Sea. Theoretically, Chinese vessels could anchor anywhere near the coast of Brunei or Indonesia and still call it territorial waters if this holds. Second, China, in reaction to attempts by the US and Japan to insert themselves into the dispute with ASEAN, began to dredge a couple of the reefs into islands. The Philippines has been protesting against Chinese actions over Mischief Reef since the 1990s, and the Chinese too were working on Tree Island and North Island, as well as Woody Islands in the Paracel Islands group. Third, the US and Japan began to act in concert with regards to aerial and naval sorties to challenge the Chinese military presence in the region, backed by an extensive media campaign against each other. In de facto terms, the US, China and Japan have militarized the South China Sea-something that ASEAN states are uncomfortable with.

This dispute enabled the US to "pivot" back into the region (Kubo 2013), as some ASEAN states such as Singapore, the Philippines and Vietnam have called on the US and other members of the international community to balance Chinese actions in the South China Sea. However, as we have seen, the South China Sea dispute(s) comprising the Spratly Islands and Paracel Islands has had a long history, and for most years of its existence, the disputes have been dormant (Catley and Keliat 1997; Chin 2003; Lo 2007; Torode and Scarr 2018). Hillary Clinton, as Secretary of State, stated in Hanoi that the South China Sea was of "core interest" to the US, much to the annoyance of the Chinese. From Beijing's perspective, all the problems, resistance and tensions in the South China Sea is a smear campaign created by Washington and Tokyo to stoke ASEAN neighbors into rallying against the rise of China. In particular, Beijing perceives that for much of the time after 2012, Prime Minister Abe's government has been instrumental in pushing for various states to help contain China, particularly in ASEAN and South Asia. In a manner characteristic of an aggrieved party, China reacted badly to the Philippines' attempt to lodge a protest with the International Tribunal for the Law of the Sea (2011) and subsequently with the Permanent Court of Arbitration (2013-2016). In response, China began to build up different reef islandsat the Subi Reef (2014), located $1200 \mathrm{~km}$ from China's coast; at Mischief Reef near to the Philippines; at Johnson South Reef (2014); and Fiery 
Cross Reef (2015). China's building exercise signaled the pyrrhic victory the Philippines had won at the international tribune. Unless the Philippines, the US and Japan are willing to attack, destroy and take control of the reefs China has occupied, little can be done to eject the Chinese from these islands. To make matters worse, reports indicated that the Chinese installations contained airstrips, air defense artillery and short-range missile encasements to strengthen its claim to sovereignty. If anything, Chinese inspiration for reclaiming the islands comes from Japan, who had largely been using similar methods to build up the islet of Okinotorishima in the Pacific since 1987.

Today, even though the Chinese staunchly defend their actions in the Spratly Islands, they are still engaging the ASEAN states and reassuring them that dialog is important, to the extent that they have agreed on an ASEAN Code of Conduct in the South China Sea. China's diplomatic moves are aimed at countering the campaign by the US and Japan to stoke up fears of a rising China in the region. Each and every member of ASEAN knows the stakes involved, the importance of keeping the sea-lanes open and free, and the importance of balancing the powers in the region. The nightmare scenario for the ASEAN states is for the US and China to ask them to choose between them. To that end, the ASEAN states will try and persuade each other to resist the division of the region collectively.

Japan's political instinct on the other hand has been to try and lobby for greater involvement of the US-Japan alliance in the region to "balance" the rising China. Today, by all indicators, Japan is doing better in terms of soft power and economic influence than China in Southeast Asia. From Tokyo's perspective, it appears imperative that Japan works with the US to balance China in the region.

As demonstrated in previous chapters, there are major challenges facing US-Japan relations too (Walsh 2007; Yabuki 2012; Mizokami 2012; Harner 2012). The US alliance with Japan and Korea also faces inherent limits (Taylor 2012). Even though Prime Minister Abe implements with zeal (Akimoto 2018), Japan itself faces a great dilemma in implementing its proactive activism (Weston 2014). As counter-intuitive as it may sound, the biggest challenge for Japanese diplomacy is to rise above this hegemonic contention between China and the US and to balance, if not moderate, the excessiveness of their confrontation. Therefore, even though Japan works with the US to prevent China from dominating the region, Japan should also try and work with China and ASEAN to moderate the excesses of the US and ensure that regional harmony is preserved. 


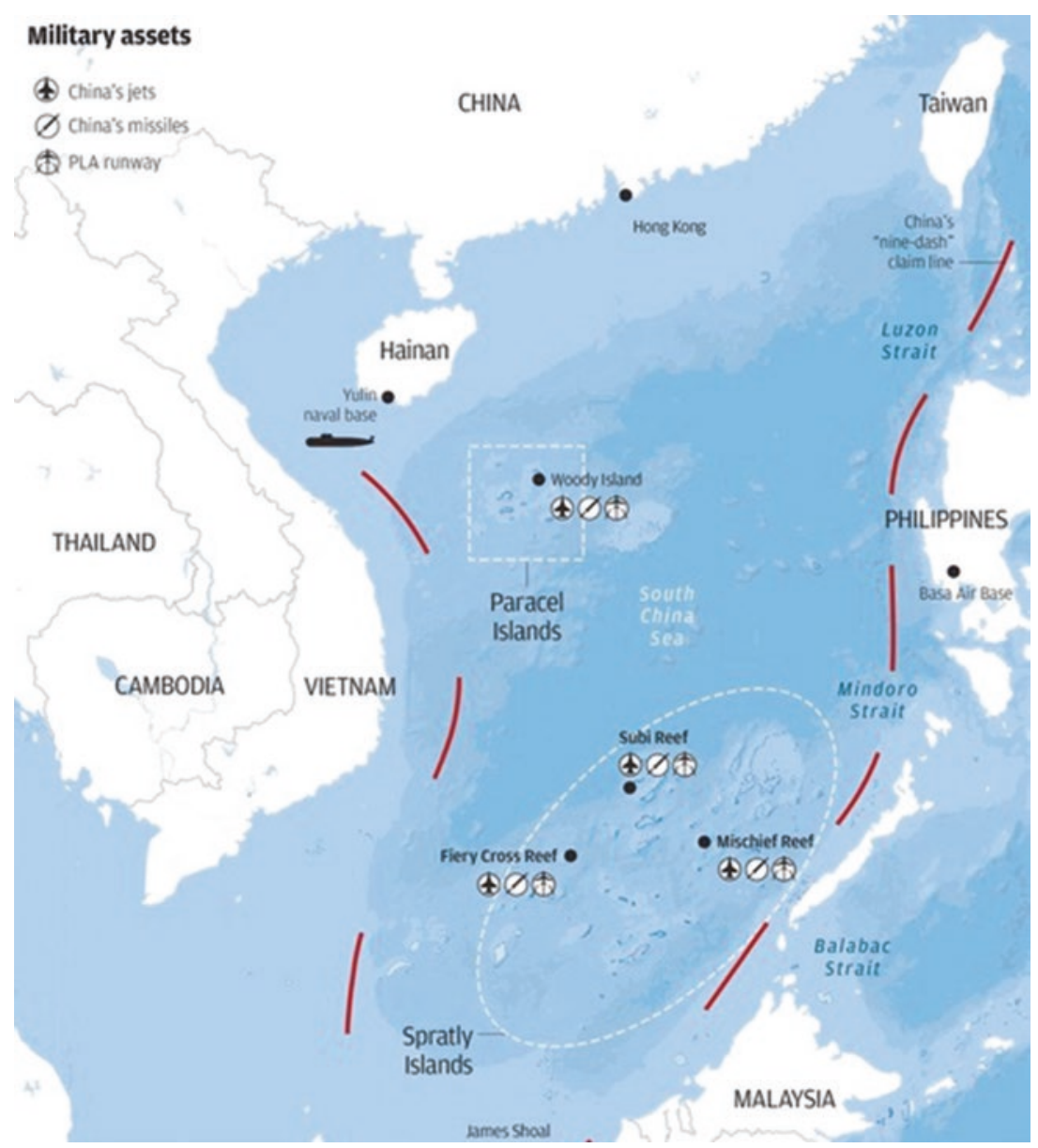

China's militarization of the South China Sea. (Reproduced with kind permission from the South China Morning Post, June 2, 2018)

Japan should be aware that ASEAN also holds reservations about Japan acting as a major military power in the region, as memories of the Second World War are still fresh in the social memories of these countries. For Japan to rise and lead as a rejuvenated power, its developmental assistance is more needed than anything else. For Japan to become respected, it must transcend the US-China divide in the region, and act as a mechanism for 
regional stability. For the most part, China's economy, like Japan's, has grown to be deeply integrated with ASEAN's economy. ASEAN states no longer believe that the US has the capacity to unilaterally drive world events. For one, the US is very much in debt and the continued projection of its power, in the Asia-Pacific and elsewhere, is heavily contingent on its debtors (in East Asia and Europe) to continually fund it by buying US Treasury bonds and using the US dollar as a reserve currency. To that extent, Japan is one of the debtors, and so is China. Admiral Mike Mullen, then chairman of the joint chief of staff, noted that China holds about USD 2 trillion in US Treasury debt, and in any confrontation China would naturally sell or ask for the demand repayment of its debt holdings (Yabuki 2012).

There is no question that the trade war today is about addressing the economic, trade and fiscal imbalance. Japan has also found itself at the receiving end of Trump's unreasonable demands. Thus, it is imperative that Japan allies itself with the ASEAN states to transcend the hegemonic struggle between China and the US as a way forward. Maneuvering ASEAN states to choose between Japan (alongside the US) or China is one of the worst ways forward for engaging Southeast Asian states. It is therefore most important for Japan to calibrate a relationship with China, because Sino-Japanese relations are historically rooted and geographically fixed, and these conditions are bound to inform the future course and relations of Sino-Japanese relations, and as such these bilateral relations must match in degree the complexity and sophistication of Japan's relations with the US (Hoshino and Satoh 2012: 181). A possible way forward is for Japan to work with ASEAN to realize the developmental potential in the region. Bread and butter, not guns, will make Southeast Asia stronger than ever before. Rather than inducing a great power competition in the region, enhancing regionalization and the integration of Southeast Asia with East Asia might be the best way for Japan to engage Southeast Asia.

\section{REFERENCES}

Akimoto, D. The Abe Doctrine: Japan's Proactive Pacifism and Security Strategy. London: Palgrave Macmillan, 2018.

Armitage, R. L., Nye, J. S., \& Center for Strategic and International Studies. The U.S. Japan Alliance: Anchoring Stability in Asia: report of the CSIS Japan chair. Washington, D.C.: Center for Strategic and International Studies, 2012. Available: https://csis-prod.s3.amazonaws.com/s3fs-public/legacy_files/files/ publication/120810_Armitage_USJapanAlliance_Web.pdf 
Araki, L. Interview with Jennifer Lind: Okinawa and the Future of the U.S.-Japan Security Alliance, The National Bureau of Asian Research, 11 May 2012, https://www.nbr.org/publication/okinawa-and-the-future-of-the-u-s-japansecurity-alliance/

Catley, R., \& Keliat, M. Spratlys: The Dispute in the South China Sea. London: Ashgate Publishing, 1997.

Chin C.Y. Potential For Conflict in the Spratly Islands, California: Naval Postgraduate School 2003, https://calhoun.nps.edu/bitstream/handle/ 10945/6221/03Dec_Chin.pdf?sequence=1

Green, M. Arming Japan: Defense Production, Alliance Politics, and the Postwar Search for Autonomy. New York: Columbia University Press, 1995.

Gurtner, F. "The Stability of the Renminbi in the Wake of the Asian financial crisis," Intereconomics 34, no. 3 (May/Jun 1999): 135-143, https://archive. intereconomics.eu/downloads/getfile.php?id=65

Harner, S. Is Japan Risking War to Save the U.S.-Japan Alliance? Forbes Online, 11 July 2012, https://www.forbes.com/sites/stephenharner/2012/11/07/ is-japan-risking-war-to-save-the-u-s-japan-alliance/

Hoshino, T., \& Satoh, H. (2012). Through the Looking Glass? China's Rise as Seen from Japan. Journal of Asian Public Policy, Vol. 5, No. 2: 181-198.

Ichiyo, M. Retaking Japan: The Abe Administration's Campaign to Overturn the Postwar Constitution. The Asia-Pacific Journal: Japan Focus. Vol. 14, Issue 13, No. 3, July 2016, https://apjjf.org/-Muto-Ichiyo/4917/article.pdf

Jain, P. Japan: The World's Next Big Arms Dealer? The National Interest, 17 Feb 2017, https://nationalinterest.org/blog/the-buzz/japan-the-worlds-next-bigarms-dealer- 19477 ?page $=0 \% 2 \mathrm{Cl}$

Kingston, J., Nationalism in the Abe Era. The Asia-Pacific Journal: Japan Focus, Vol. 14, Issue 20, No. 3, Oct 2016, https://apjjf.org/2016/20/Kingston.html

Kubo, F. The Second-Term Obama Administration and Japan. Asia-Pacific Review, 20(1), 24-34, 2013, https://doi.org/10.1080/13439006.2013.788339

Lo, C.K. China's Policy Towards Territorial Disputes. London: Taylor \& Francis, 2007.

Martin, C. Jus ad Bellum Implications of Japan's New National Security Laws, Opiniojuris, 2016, http://opiniojuris.org/2016/04/21/jus-ad-bellum-implicationsof-japans-new-national-security-laws/

McCormack, G. Ampo's Troubled 50th: Hatoyama's Abortive Rebellion, Okinawa's Mounting Resistance and the US-Japan Relationship, The AsiaPacific Journal: Japan Focus, Vol. 8, Issue 22, No. 3, 2010, https://apjjf.org/Gavan-McCormack/3365/article.html

McCormack, G. (2016). Japan: Prime Minister Abe Shinzo's Agenda, The AsiaPacific Journal: Japan Focus, Vol. 14, Issue 24, No. 1, 2016, https://apjjf. org/2016/24/McCormack.html

Mizokami, K. Japan and the U.S.: It's Time to Rethink Your Relationship, The Atlantic, 27 Sep 2012, https://www.theatlantic.com/international/ 
archive $/ 2012 / 09 /$ japan-and-the-us-its-time-to-rethink-your-relationship/262916/

Pejsova, E. \& Stanley, Z., Japan's Policy Shift: Arms and Transfers, Zurich: ETH Center for Security Studies, 2016, http://www.css.ethz.ch/en/services/digitallibrary/articles/article.html/269f638b-c376-4ld4-a804-da7ldc78475f/pdf

Samuels, J. S. Securing Japan. Ithaca and London: Cornell University Press, 2007. Samuels, R.J. “Rich Nation, Strong Army”: National Security and the Technological Transformation of Japan. Ithaca, NY: Cornell University Press, 1994.

Soeya, Y. China, and Japan's foreign policy posture, East Asia Forum, 8 April 2012, http://www.eastasiaforum.org/2012/04/08/china-and-japans-foreign-policy-posture/

Tawara, Y. (Translated by Brooks, W., Lu, P., Asia Policy Point) What is the Aim of Nippon Kaigi, the Ultra-Right Organization that Supports Japan's Abe Administration?, The Asia-Pacific Journal: Japan Focus, 1st Nov 2017, Vol. 15, Issue 21, No. 1, https://apjjf.org/2017/21/Tawara.html

Taylor, B. Japan and South Korea: The Limits of Alliance. Survival, 54(5), 93-100, 2012, https://doi.org/10.1080/00396338.2012.728346

Torode, G., \& Scarr, S. Concrete and Coral: Beijing's South China Sea Building Boom fuels concerns, Reuters, 24 May 2018.

Walsh, B. Why Japan Is Unhappy with the U.S., Times Magazine, 21 Feb 2007, http://content.time.com/time/world/article/0,8599,1592181,00.html

Weston, S. A. The Dilemma of Japan's Proactive Pacifism in Asia, Fukuoka University Review of Law, Vol. 59, No. 2, pp 169-212, Sep 2014.

White, H., The China Choice: Why We Should Share Power, Oxford and New York: Oxford University Press, 2013.

Yabuki, S. US-China-Collusion-and-the-Way-Forward-for-Japan, East Asia Forum, 30 June 2012, http://www.eastasiaforum.org/2012/06/30/uschinacollusion-and-the-way-forward-for-japan/

Open Access This chapter is licensed under the terms of the Creative Commons Attribution 4.0 International License (http://creativecommons.org/licenses/ by $/ 4.0 /$ ), which permits use, sharing, adaptation, distribution and reproduction in any medium or format, as long as you give appropriate credit to the original author(s) and the source, provide a link to the Creative Commons licence and indicate if changes were made.

The images or other third party material in this chapter are included in the chapter's Creative Commons licence, unless indicated otherwise in a credit line to the material. If material is not included in the chapter's Creative Commons licence and your intended use is not permitted by statutory regulation or exceeds the permitted use, you will need to obtain permission directly from the copyright holder.

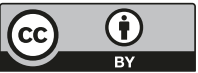

